Al Qalam: Jurnal Ilmiah Keagamaan dan Kemasyarakatan https://jurnal.stiq-amuntai.ac.id/index.php/al-qalam

\title{
TRANSMISI ILMU TASAWUF TUAN GURU DI KALIMANTAN SELATAN
}

\author{
Oleh \\ Asmaran (Deson UIN Antasari Banjarmasin) E-mail: \\ asmaran.asmullah@gmail.com, Husnul Yaqin (Dosen UIN Antasari Banjarmasin) \\ E-mail: husnulyaqin@uin-antasari.ac.id , dan Mahmud (Dosen STAI Rakha \\ Amuntai) \\ E-mail: mahmudibnuramli@gmail.com
}

\begin{abstract}
Abstrak
Fokus penelitian ini adalah menelaah bagaimana jaringan ilmu tasawuf Tuan Guru di Kalimanatan Selatan Pendekatan penelitian ini adalah kualitatif dan lapangan. Jenis penelitian yang digunakan adalah penelitian deskriptif . Hasil temuan dalam penelitian ini adalah: 1). Jaringan ilmu tasawuf Tuan Guru di Kalimantan Selatan berporos pada beberapa daerah utama yaitu Martapura, Nagara (Kandangan), Barabai, Amuntai, Rantau (Tapin), Banjarmasin, dan Tabalong. 2). Materi penyampaian ilmu tasawuf Tuan Guru di Kalimantan Selatan yaitu Pertama, Tasawuf Akhlaqi yang terdiri dari takhalli, tahalli, tajalli. Kitab yang membahasnya adalah Ihyâ 'Ulǔmuddîn, Nashâihuddîniyyah, Al-Hikam, dan Bidâyatul Hidâyah. Kedua, Tasawuf Amali yang terdiri dari syarî'ah, tharîqah, haqîqah, dan ma'rifah. Kitab yang membahasnya adalah Ihyâ Ulǔmuddîn, Nashâihuddîniyyah, Al-Hikam, dan Bidâyatul Hidâyah. Ketiga, Tasawuf Falsafi yang terdiri dari fanâ dan baqâ, ittihâd, hulǔl, wihdatul wujǔd, dan isyrâq. Kitab yang membahasnya adalah Kifâyatul Atqiyâ, Nashâihul 'Ibâd, Tuhfaturrâghibîn, dan Durrun Nafis. Keempat, Manâqib yang terdiri dari manâqib Siti Khadijah dan manâqib Syekh Samman Al-Madâni. Kitab yang membahasnya adalah kitab manâqib Siti Khadijah dan kitab manâqib syekh Samman Al-Madani. 3). Metode penerimaan dan penyampaian ilmu tasawuf Tuan Guru di Kalimantan Selatan yaitu Pertama, Shuhbah berupa khidmah dan mulâzamah. Kedua, riyâdhah dan mujâhadah berupa pengamalan ilmu dan muthâla'ah. Ketiga, dzikir berupa râtib dan wirîd. Keempat, tharîqah berupa Sammâniyyah, Naqsyabandiyyah, Qadariyyah, dan Alawiyyah. Kelima, Insiasi Spritual berupa bai'at, tharîqat naqsyabandiyyah, darkah yahlal madînah, jam'iyyah ahli tharîqah. Keenam, khirqah berupa pemakaian imâmah, penyerahan tasbih, penyerahan tongkat, dan penjamuan tamu bil-aswidatain (kurma dan zamzam).

Kata Kunci: Transmisi, Materi Penyampaian, Metode Penerimaan dan Penyampaian.
\end{abstract}

\section{PENDAHULUAN}

Kalimantan Selatan merupakan provinsi yang dihuni oleh mayoritas suku Banjar. Orang banjar dikenal sebagai pemeluk agama Islam. Berdasarkan sensus yang ada pada tahun 2018, jumlah pemeluk agama Islam di Kalimantan Selatan adalah pemeluk agama terbesar jika

Al Qalam: Jurnal Ilmiah Keagamaan dan Kemasyarakatan Vol. 16, No. 2

Maret - April 2022 
dibandingkan dengan pemeluk agama yang lain Jumlah yang besar ini tentu bukan sesuatu yang terwujud secara tiba-tiba. Ia adalah hasil dari usaha-usaha perjuangan yang dilakukan oleh tokohtokoh Islam yang disebut dengan ulama. Karena itu pula, ulama memiliki kedudukan penting dalam kehidupan masyarakat Banjar hingga sekarang. ${ }^{1}$

Islam banyak memiliki cara dalam menerima dan menyampaikan ilmu pengetahuan dengan kebudayaan yang beragam. Pengkajian khusus tentang dan cara-cara penerimaan, penyampaian, penyebaran ilmu pengetahuan kepada murid-muridnya, serta materi penyampaian keilmuan ulama sangat penting, karena hal itu dapat menunjang pemahaman dan pengamalan masyarakat terhadap ajaran agama Islam yang mereka peroleh, serta akan menarik minat mereka untuk mengkaji ilmu pengetahuan lebih mendalam.

Lebih dari itu, ulama juga dituntut untuk dapat menjadi panutan (qudwah), sehingga keberadaannya senantiasa memancarkan sinar kebajikan dan menjadi suri teladan bagi orang lain. Cahaya kebajikan yang dipancarkan oleh ulama benar-benar menjadi penerang bagi orang lain untuk menapaki jalan yang lurus (as-shirâthal mustaqîm), bukan saja ketika masa hidupnya tetapi juga ketika sudah meninggal dunia.

Peran ulama sebagai pengayom dan pelipur hati masyarakat, dapat terjadi secara tidak langsung, yakni di pengajian-pengajian yang ia berikan. Sebagian masyarakat menyukai pengajian seorang ulama karena merasakan kedamaian dalam mendengarkan nasihat-nasihatnya. Hati yang sebelumnya sedih dan gundah, setelah menghadiri dan mendengarkan petuah-petuah keagamaan di majelis-majelis pengajian ulama, maka hati mereka menjadi tenang oleh siraman nasihat-nasihatnya. Boleh jadi pula masyarakat menyenangi ceramah seorang ulama karena banyak lelucon darinya, sehingga para pendengarnya terhibur dan tertawa. Adapula seorang ulama yang disukai jamaahnya karena suaranya yang merdu menyentuh hati. Mungkin pula ia disenangi masyarakat karena kemampuannya menjelaskan konsep-konsep agama yang rumit menjadi mudah dan aktual bagi kehidupan sehari-hari. Di tengah berbagai krisis kehidupan yang serba materialis, sekular serta kehidupan yang sangat sulit secara ekonomi maupun jiwa, tasawuf memberikan solusi penawar rohani, yang memberi daya tahan.

Ilmu tasawuf merupakan salah satu bidang studi Islam yang memusatkan perhatian pada pembersihan aspek rohani manusia yang selanjutnya dapat menimbulkan akhlak mulia. Pembersihan aspek rohani atau batin ini selanjutnya dikenal sebagai dimensi esoterik dari diri manusia. Salah satu ilmu yang dapat membantu terwujudnya manusia yang berkualitas adalah

${ }^{1}$ Mujiburrahman, Selayang Pandang Ulama Banjar Dari Masa Ke Masa, (Banjarmasin: Abadi Offset, 2011): hal. xxi

Al Qalam: Jurnal Ilmiah Keagamaan dan Kemasyarakatan Vol. 16, No. 2

Maret - April 2022 
ilmu Tasawuf. Tasawuf sebagai sumsum tulang atau dimensi dalam, dari wahyu keislaman, adalah upaya dalam yang luhur, dimana tauhid tercapai. Demikian pentingnya peranan tasawuf dalam kelangsungan hidup manusia seutuhnya, maka tidak mengherankan apabila tasawuf demikian akrab dengan kehidupan masyarakat Islam,

Tuan Guru di Kalimantan Selatan memiliki transmisi ilmu tasawuf yang menarik. Mereka berhasil menghembus roh Islami kepada murid-muridnya. Yang lebih menarik lagi, mereka juga dikenal sebagai tokoh masyarakat yang terbukti mempunyai kemampuan untuk mengatasi berbagai permasalahan kehidupan masyarakat. Dalam transmisi ilmu tasawuf, mereka memiliki karakteristik khusus yang akan menjadi daya tarik masyarakat untuk menimba ilmu. Disadari bahwa hal tersebut sangat mempengaruhi sistem pendidikan yang mereka emban. Sebagaimana juga terjadi di berbagai daerah lainnya di Indonesia, Islam masuk ke Kalimantan Selatan bersama faham tasawuf, bahkan mengarah pada sufi-akidah (mistik). ${ }^{2}$ Dalam piagam Kerajaan Banjar yang berbentuk segi empat, di tengah-tengahnya tersusun angka-angka huruf Arab, suatu kebiasaan yang dipercaya mengandung kekuatan gaib dan digunakan dalam aliran magic dan dinamisme di Persia, dan pada samping bawah batu tertulis "Lâllâha illallâhua, Allâhu maujud aku", kalimat yang biasa dipergunakan oleh sebagian pengikut aliran wihdatul wujud. ${ }^{3}$ Bahkan Khatib Dayyan yang dikirim sebagai wakil Demak ke Banjar juga merupakan seorang sufi. ${ }^{4}$ Kepeloporan dan kebijaksanaan serta transmisi ilmu yang dipraktikkan kepada muridnya dan masyarakat luas telah banyak menyumbangkan kualitas kader bangsa ini yang lebih dinamis terutama di kalangan majelis ta'lim serta dapat lebih memberikan sumbangan yang berharga dalam rangka pengembangan pembelajaran agama Islam di Kalimantan Selatan.

Berpijak pada paradigma pemikiran dan kenyataan di atas, penulis tertarik untuk meneliti lebih mendalam tentang bagaimana transmisi ilmu tasawuf Tuan Guru di Kalimantan Selatan.

\section{HASIL DAN PEMBAHASAN}

\section{Transmisi Ilmu Tasawuf Tuan Guru di Kalimantan Selatan}

\footnotetext{
${ }^{2}$ Para sufi dipandang memainkan peran penting dalam konversi penduduk lokal ke dalam Islam, karena mereka mampu memelihara kontinuitas kepercayaan dan praktik keberagamaan penduduk lokal, sehingga agama baru tidak dianggap sebagai sesuatu yang asing, aneh, dan membahayakan. Sejumlah sufi juga tercatat melakukan ikatan pernikahan dengan anak para bangsawan kerajaan, yang kemudian memberikan efek positif kepada perkembangan Islam di Nusantara. Lihat Miftah Arifin, Sufi Nusantara (Yogyakarta: ar Ruzz Media, 2013), h. 23-24

${ }^{3} \mathrm{Gt}$. Abd. Muis, Masuk dan Tersebarnya Islam di Kalimantan Selatan, makalah disampaikan dalam Pra Seminar Sejarah Kalimantan Selatan Tanggal 23-25 September 1973, h. 43

${ }^{4}$ Noor Syahidah Mohamad Akhir, Pengaruh Syeikh Muhammad Nafis al-Banjari di Kalimantan Selatan Berhubung Ilmu Tasawuf dalam Prosiding Nadwah Ulama Nusantara (NUN) IV: Ulama Pemacu Transformasi Negara(Selangor: Universiti Kebangsaan Malaysia, 2011), h. 357.
}

Al Qalam: Jurnal Ilmiah Keagamaan dan Kemasyarakatan Vol. 16, No. 2 Maret - April 2022 
Terbentuknya jaringan ulama dan keilmuan dalam Islam khususnya dalam bidang ilmu tasawuf tidak dapat dipisahkan dari perkembangan awal tradisi Islam itu sendiri khususnya yang terkait dengan dengan proses penyebaran dan transmisi ilmu tersebut. Sehingga pengkajian khusus dalam transmisi ilmu tasawuf menjadi salah satu topik pembicaraan yang sangat menarik untuk diperhatikan. Hal terrsebut sebagaimana yang dikatakan oleh Prof. Dr. Azyumardi Azra dalam bukunya "Jaringan Ulama".

Transmisi ilmu tasawuf yang dimaksudkan di sini adalah penerimaan dan penyampaian ilmu tasawuf, serta penyandaran ilmu tasawuf itu kepada para guru-gurunya yakni dari siapa ilmu tersebut didapatkan dan kepada siapa pula ilmu tersebut disampaikan. Dalam transmisi ilmu setidaknya tercakup tiga unsur kegiatan: (1) menerima ilmu dari gurunya; (2) menyampaikan ilmu kepada muridnya; dan (3) ketika menyampaikan ilmu itu, mata-rantai ilmunya juga disebutkan. Dalam proses transmisi ilmu tasawuf tersebut terjalin hubungan yang kompleks dan saling silang antara Tuan Guru dan murid, sesama Tuan Guru itu sendiri, ataupun sesama murid itu sendiri, dan akan membentuk semacam "jaringan" yang dikenal dengan istilah sanad atau isnâd

Berdasarkan sejarah dinyatakan bahwa Islam sudah masuk ke wilayah Banjar sejak abad ke-16, namun Islamisasi yang secara intensif baru mulai pada abad ke-18 dengan tokoh sentralnya Tuan Guru Haji Muhammad Arsyad Al-Banjari (1710-1812 M). Ia merupakan sosok ulama Banjar paling awal, yang sejarah hidupnya menjadi contoh bagi ulama-ulama di kemudian hari. Pada usia 30 tahun, Tuan Guru Haji Muhammad Arsyad Al-Banjari dikirim oleh Sultan Tamjidillah (1734-1759 M) ke tanah suci untuk berhaji sekaligus menuntut ilmu agama Islam. Menurut sejarah, Tuan Guru Haji Muhammad Arsyad Al-Banjari mengkaji ilmu agama Islam di Masjidil Haram Mekkah selama kurang lebih 30 tahun. Kemudian Ia pindah ke Madinah, dan belajar di kota sana selama 5 tahun. Selama periode itu, Ia tidak hanya belajar, tapi juga mengajarkan ilmu yang telah diperolehnya kepada orang lain. Tuan Guru Haji Muhammad Arsyad Al-Banjari pulang ke tanah air pada 1772 M. Setelah tiba di kesultanan Banjar, ia diberi Sultan Tahmidullah II (1781-1801 M) sebuah lahan yang cukup luas. Di situ kemudian dibagun perumahan sekaligus langgar sebagai tempat beribadah dan belajar. Ketika itu, orang-orang yang menjadi murid Tuan Guru Haji Muhammad Arsyad Al-Banjari terdiri dari keluarganya, anakanak dan cucu-cucunya, di samping orang-orang yang bukan dari keluarganya sendiri.

Tuan Guru ilmu tasawuf yang sezaman dengan Tuan Guru Haji Muhammad Arsyad Al-Banjari adalah Tuan Haji Muhammad Nafis bin Idris Al-Banjari. Ia dilahirkan di Martapura pada tahun 1735 M, dalam keluarga bangsawan, Muhammad Nafis hidup pada periode yang sama dengan Syeikh Muhammad Arsyad al-Banjari. Dan Ia wafat sekitar tahun

Al Qalam: Jurnal Ilmiah Keagamaan dan Kemasyarakatan Vol. 16, No. 2 Maret - April 2022 
Asmaran, Husnul Yaqin, Mahmud : Transmisi Ilmu Tasawuf Tuan Guru di Kalimantan Selatan

1812 M. dan dimakamkan di Mahar Kuning, Desa Binturu, sekarang menjadi bagian desa dari Kecamatan Kelua, Kabupaten Tabalong.

Para Tuan Guru yang pergi ke Haramain di akhir abad ke-19 umumnya terlebih dahulu belajar di Dalam Pagar dengan Tuan Guru Haji Muhammad Arsyad Al-Banjari, baru kemudian setelah itu berangkat ke sana. Sedangkan mereka yang ke Haramain di abad ke-20, kebanyakan sudah belajar ilmu agama Islam di berbagai lembaga pendidikan yang sudah tersebar di Kalimantan Selatan seperti di Nagara (Hulu Sungai Selatan), Amuntai (Hulu Sungai Utara), Barabai (Hulu Sungai Tengah) dan Martapura (Kabupaten Banjar).

Salah satu pusat pendidikan Agama Islam di luar Dalam Pagar, yang berkembang pesat mulai akhir abad ke-19 adalah di Nagara, Kandangan Hulu Sungai Selatan. Jaringan Tuan Guru di Nagara dapat ditelusuri sampai ke Tuan Guru Haji Muhmmad Arsyad Al-Banjari. Salah seorang murid Tuan Guru Haji Muhmaad Arsyad Al-Banjari adalah Tuan Guru Haji Sa'duddin atau yang lebih akrab disebut dengan penggilan Datu Taniran. Di antara murid-muridnya di Taniran adalah Tuan Guru Haji Muhammad Thahir (Datu Daha) asal Nagara, yang juga melanjutkan belajarnya ke Haramain. Di antara muridnya yang belajar kepadanya khususnya dalam bidang ilmu tasawuf adalah: Tuan Guru Haji Abdurrasyid yang berasal dari Amuntai.

Tuan Guru Haji Abdurrasyid banyak memiliki murid yang menjadi penerus estafet perjuangannya khususnya dalam mengembangkan ilmu tasawuf. Di antara murid-muridnya yang terkenal dengan ilmu tasawufnya adalah Tuan Guru Haji Abdul Wahab Sya'rani, Tuan Guru Haji Nabhani Rasyid, Tuan Guru Haji Rawi, Tuan Guru Haji Imran dikenal dengan sebutan Bung Tomo, Tuan Guru Haji Utsman (Pandai, Kandangan), Tuan Guru Haji Napiah, Tuan Haji Kaderi, Tuan Guru Haji As'ad (Barabai), Tan Sri Abdul Jalil (Malaysia) dan lain-lain. Tuan Guru Haji Abdul Wahab Sya'rani memiliki murid yang meneruskan perjuangannya dalam menyebarkan agama Islam khususnya dalam penyebaran dan pengajaran ilmu tasawuf. Di antara muridmuridnya yang menjadi Tuan Guru khususnya dalam bidang ilmu tasawuf sepeninggalnya adalah Tuan Guru Haji Syaukani Lc, Tuan Guru Haji Janawi, Tuan Guru Haji Abdullah Gawang, dan lain-lain. Tuan Guru Haji Janawi juga memiliki murid yang menjadi Tuan Guru ilmu tasawuf di desa Sungai Sandung Alabio yaitu Tuan Guru Haji Abdul Bari. Sedangkan Tuan Guru HajiAbdullah Gawang adalah mertua dari Tuan Guru Haji abdul Bari yang sekaligus juga salah satu guru ilmu tasawufnya. Tuan Guru Haji Syaukani Lc, yang terkenal sebagai seorang pemimpin tarikat Qadariyah wa Naqsyabandiyyah di daerah Amuntai juga memiliki murid yang menjadi Tuan Guru dalam bidang ilmu tasawuf di antaranya Tuan Guru Haji Hanafi Idar, Tuan Guru Haji Najmuddin (Barabai), Tuan Guru Haji Hifni dan lain-lain.

Al Qalam: Jurnal Ilmiah Keagamaan dan Kemasyarakatan Vol. 16, No. 2 Maret - April 2022 
Asmaran, Husnul Yaqin, Mahmud : Transmisi Ilmu Tasawuf Tuan Guru di Kalimantan Selatan

Tuan Guru Utsman yang berasal dari Pandai, Kandangan kabupaten Hulu Sungai Selatan yang merupakan salah satu dari murid Tauan Guru Haji abdurrasyid, juga menurunkan ilmunya khususnya ilmu tasawuf kepada murid sekaligusnya anaknya sendiri yaitu Tuan Guru Haji Abdul Aziz dan Tuan Guru Haji Abdul Aziz juga mengajarkan ilmu tasawufnya kepada murid-muridnya dan anaknya sendiri yaitu kepada Ustadz Dihyauddin. Sedangkan Tuan Guru Haji Nafiah adalah salah satu guru ilmu tasawuf dari Tuan Guru Haji Husin Naparin dan Tuan Guru Haji Nabhani Rasyid adalah salah satu guru ilmu tasawuf dari Prof. Dr. Haji Zurkani Yahya.

Tuan Guru terkenal khususnya dalam bidang ilmu tasawuf yang berasal dari Barabai, yaitu Tuan Guru Haji Muhammad Ramli, orang tua dari Tuan Guru Haji Mahfuz Amin, pendiri Pesantren Ibnu Al-Amin Pemangkih yang berdiri pada tahun 1958, juga pernah belajar di Nagara dengan Tuan Guru Haji Muhammad Thahir (Datu Daha). Ia adalah Tuan Guru yang menjadi panutan dan pedoman bagi masyarakat pada waktu itu. Ia mengajarkan ilmunya khususnya dalam bidang ilmu tasawuf kepada murid dan anakanya sendiri yaitu Tuan Guru Haji Mahfudz Amin yang sangat sangat terkenal sebagai pendiri pondok pesantren Ibnu Al-Amin Pamangkih. Salah satu murid dari Tuan Guru Haji Mahmfudz Amin yang terkenal di daerah Longawang yaitu Tuan Guru Haji Taris atau dikenal dengan sebutan Haji Tukad Longawang. Haji Tukad merupakan orang tua sekaligus guru dari Tuan Guru Haji Kaderi Longawang yang terkenal dengan ilmu tasawufnya di daerah tersebut.

Tuan Guru Haji Ahmad Mughni merupakan Tuan Guru kharismatik pada masanya, biasa disebut Guru Nagara atau Ayah Nagara, karena bertempat tinggal di Nagara Kabupaten Hulu Sungai Selatan. Tuan Guru Haji Ahmad Mughni mengkaji ilmu agama khususnya di bidang ilmu tasawuf dengan ayahnya sendiri yaitu Tuan Guru Haji Ismail Alabio yang terkenal dengan keilmuan tasauwufnya pada masa itu sehingga Ia memiliki banyak murid. Di antara muridnya yang terkenal yang mewarisi ilmu tasawufnya selain anaknya sendiri adalah Tuan Guru Haji Taris atau yang terkenal dengan sebutan $\mathrm{H}$. Tukad yang berasal dari Longawang Kandangan Hulu sungai Selatan, dan Ia menurunkan ilmunya khususnya ilmu tasawufnya kepada murid sekaligus anaknya sendiri yaitu Tuan Guru Haji Kaderi.

Tuan Guru Haji Ahmad Mughni selain sebagai seorang ayah, Guru Ahmad Mughni juga merupakan guru spiritual (ilmu batin) bagi Tuan Guru Haji Muhammad Bakhiet. Nasabnya bersambung kepada Tuan Guru Haji Muhammad Arsyad Al-Banjari, yaitu Tuan Guru Haji Muhammad Bakhiet (Barabai) bin Tuan Guru Haji Ahmad Mughni (Nagara) bin Tuan Guru Haji Ismail (Alabio) bin Tuan Guru Haji Muhammad Thahir (Alabio) bin Khalifah Haji Syihabuddin

Al Qalam: Jurnal Ilmiah Keagamaan dan Kemasyarakatan Vol. 16, No. 2 Maret - April 2022 
Asmaran, Husnul Yaqin, Mahmud : Transmisi Ilmu Tasawuf Tuan Guru di Kalimantan Selatan

(Pulau Penyangat-Kepulauan Riau) bin Maulana Syekh Muhammad Arsyad al-Banjari (Martapura).

Di Kalimantan Selatan, Guru Sekumpul masyhur sebagai pengajar tarekat Sammaniyah. Aliran salik ini didirikan Muhammad bin Abdul Karim, sosok dari awal abad ke-18 yang lahir di Madinah. Di Martapura dan sekitarnya, Guru Sekumpul mengajarkan tarekat Sammaniyah kepada para muridnya, setidaknya mulai semarak sejak 1994. Sanad yang disambungkan dia berasal pula dari Syekh Muhammad Arsyad al-Banjari. Guru Sekumpul memiliki sejumlah pengikut dalam kajian tarekat ini. Di antaranya adalah Tuan Guru Haji Muhammad Syukeri Unus (Martapura), Tauan Guru Haji Zarkasyi (Martapura) yang mana ia memiliki murid yang mewarisi ilmunya khususnya dalam bidang ilmu tasawuf yaitu As-Sayyid Abdussalam Al-Kaff (Gambah), Tuan Guru Asmuni yang terkenal dengan panggilan Guru Danau (Amuntai) Hulu Sungai Utara, Ia memiliki murid yang mengajarkan ilmu tasawuf juga yaitu Tuan Guru Haji Dahlan (Teluk Daun, Amuntai), Tuan Guru Haji Muhammad Ridwan terkenal akrab dengan sebutan Guru Kapuh, Kandangan Hulu Sungai Selatan, Tuan Guru Ahmad Syairazi (Kandangan), Tuan Guru Haji Ahmad Barmawi atau terkenal dengan sebutan Tuan Guru Muda atau Guru Kulur, Tuan Guru Haji Ahmad Sanusi atau Guru Jaro, Tuan Guru Zuhdiannor (Guru Zuhdi), dan lain-lain.

Transmisi ilmu tasawuf Tuan Guru Haji Zaini bin Abdul Gahani (Guru Sekumpul) dapat ditelusuri samapai kepada Tuan Guru Haji Muhammad Arsyad Al-Banjari (Guru Kalampayan). Guru sekumpul mengambil ilmu tasawufnya kepada Tuan Guru Haji Muhammad Syarwani Abdan (Guru Bangil). Selain Guru Sekumpul murid Guru Bangil yang terkenal dengan ilmu tasawufnya adalah Tuan Guru Haji Masrani Hamdan (Amuntai) dan Tuan Guru Haji Anang Ramli (Bati-Bati) dan Ia memiliki murid yang ahli di bidang ilmu tasawufnya yaitu Tuan Guru Haji Mahmud Hashil. Tuan Guru Haji Muhammad Syarwani Abdan mengambil ilmunya khususnya dalam bidang ilmu tasawuf kepada Tuan Guru Haji Zainuddin As-Sumbawi dan Ia mengambil ilmu tasawufnya kepada Tuan Guru Haji Nawawi Al-Bantani dan Ia mengambil ilmu tasawufnya kepada Tuan Guru Haji Syihabuddin, dan Ia mengambil ilmu tasawufnya kepada Tuan Guru Haji Muhammad Arsyad Al-Banjari.

Selain kepada Tuan Guru Haji Zainuddin As-Sumbawi, Tuan Guru Haji Muhammad Syarwani Abdan (Guru Bangil) juga mengambil ilmu tasawufnya kepada Tuan Guru Haji Kasyful Anwar. Yang mana Tuan Guru Haji Kasyful Anwar pada waktu itu juga memiliki murid lain selain Guru Bangil yang mengkaji ilmu kepadanya khususnya dalam bidang ilmu tasawuf yaitu Tuan Guru Haji Seman Mulia, Tuan Guru Haji Abdul Qadir Hasan, Tuan Guru Haji Abdul Muis. Tuan Guru Haji Seman Mulia memiliki murid yang mengakaji ilmu tasawuf kepadanya yaitu

Al Qalam: Jurnal Ilmiah Keagamaan dan Kemasyarakatan Vol. 16, No. 2 Maret - April 2022 
Asmaran, Husnul Yaqin, Mahmud : Transmisi Ilmu Tasawuf Tuan Guru di Kalimantan Selatan

Tuan Guru Haji Muhammad Dahlan (Guru Cantung) dan Ia memiliki murid yang ahli di bidang ilmu tasawufnya yaitu Tuan Guru Haji Hanafi Gubet. Sedangkan Tuan Guru Haji Abdul Qadir Hasan juga memiliki 2 murid yang ahli di bidang ilmu tasawuf yaitu Tuan Guru Haji Muhammad Ridwan yang terkenal dengan sebutan Guru Lok Bangkai Amuntai dan Tuan Guru Haji Hamdan Khalid Amuntai.

Tuan Guru Haji Kasyful Anwar mempelajari ilmu tasawuf khususnya kepada gurunya yaitu Tuan Guru Haji Abdullah Khatib, dan Ia mempelajari ilmu tasawufnya kepada Tuan Guru Haji Muhammad Shalih, dan Ia mempelajari ilmu tasawufnya kepada Tuan Guru Haji Hasanuddin, Ia mempelajari ilmu tasawufnya kepada Tuan Guru Haji Muhammad Arsyad AlBanjari.

Di Marabahan Tuan Guru yang terkenal dengan ilmu tasawufnya adalah Tuan Guru Haji Basyuni Marabahan yang mana Ia juga merupakan salah satu guru ilmu tasawuf dari Tuan Guru Haji Muhammad Zaini bin Abdul Ghani (Guru Sekumpul) Martapura. Guru Sekumpul semasa hidupnya sering menemui dan mempelajari ilmu tasawuf kepada Tuan Guru Haji Basyni tersebut. Tuan Guru Haji Basyuni Marabahan mempelajari ilmu tasawufnya kepada Tuan Guru Haji Abdusshamad, Ia mempelajari ilmu tasawufnya kepada Tuan Guru Haji Mufti Jamaluddin, dan Ia mempelahari ilmu tasawufnya kepada Tuan Guru Haji Muhammad Arsyad Al-Banjari (Datu Kalampayan).

Pengarang kitab Senjata Mu'min yaitu Tuan Guru Haji Husin Qadri terkenal dengan Tuan Guru yang ahli di bidang ilmu tasawufnya memiliki 4 orang murid yang ahli di bidang ilmu tasawuf yaitu Tuan Guru Haji Rafi'I Hamdi, Tuaan Guru Haji Syaifuddin Zuhri, Tuan Guru Haji Muhammad Dahlan, dan Tuan Guru Haji Muhammad Ridwan (Guru Lok Bangkai, Amuntai). Guru Lok Bangkai memiliki murid yang ahli di bidang ilmu tasawufnya yaitu Tuan Guru Haji Ahmad Mu'thi Amuntai, pendiri pondok pesantren Raudhatut Thalibin Amuntai. Tuan Guru Haji Husin Qadri mengambil ilmu tasawufnya kepada Tuan Guru Haji Zainal Ilmi, dan Ia mempelajari ilmu tasawufnya kepada Tuan Guru Haji Abdurrahman Shidiq, dan Ia mempelajari ilmu tasawufnya kepada Tuan Guru Haji Said Wali dan Tuan Guru Said Wali mempelajari ilmu tasawufnya kepada Tuan Guru Haji Muhammad Arsyad Al-Banjari (Datu Kalampayan).

Di Basirih terdapat juga Tuan Guru ilmu tasawuf yang masyhur (terkenal) yang merupakan keturunan dari habaib (cucu Rasulullah SAW) yaitu Al-Habib Abu Bakar Bahasyim atau yang lebih akrab dipanggil dengan sebutan Habib Basirih. Habib Basirih belajar ilmu tasawuf kepada ayahnya sendiri yaitu Al-Habib Hamid Bahasyim, dan Al-Habib Hamid Bahasyim belajar

Al Qalam: Jurnal Ilmiah Keagamaan dan Kemasyarakatan Vol. 16, No. 2

Maret - April 2022 
Asmaran, Husnul Yaqin, Mahmud : Transmisi Ilmu Tasawuf Tuan Guru di Kalimantan Selatan

ilmu tasawuf dengan Mufti Haji Muhammad As'ad, sedangkan Mufti Haji Muhammad As'ad belajar ilmu tasawuf dengan Tuan Guru Haji Muhammad Arsyad Al-Banjari.

\section{Materi Penyampaian Ilmu Tasawuf Tuan Guru di Kalimantan Selatan}

\section{a. Tasawuf Akhlâqi}

Secara etimologis, tasawuf akhlâqi bermakna membersihkan tingkah laku atau saling membersihkan tingkah laku. Jika konteksnya adalah manusia, maka tingkah laku manusia yang menjadi sasarannya. Tasawuf akhlaqi ini bisa dipandang sebagai sebuah tatanan dasar untuk menjaga akhlak manusia, atau dalam bahasa sosialnya, yaitu moralitas masyarakat. Oleh karena itu, tasawuf akhlaqi merupakan kajian ilmu yang sangat memerlukan praktik untuk menguasainya. Tidak hanya berupa teori sebagai sebuah pengetahuan, tetapi harus dilakukan dengan aktifitas kehidupan manusia. Di antara kitab-kitab ilmu tasawuf yang membahas tentang akhlak adalah kitab Ihyâ 'Ulǔmuddîn karya Imam Muhammad bin Muhammad bin Muhammad bin Ahmad, Imam Besar Abu Hamid Al-Ghazali Hujjatul Islam. Kitab tersebut selalu dibaca dan diajarkan oleh Tuan Guru di Kalimantan Selatan di majelis-majelis ta'lim mereka seperti Tuan Guru Haji Muhammad Sykri Unus (Martapur), Tuan Guru Haji Zarkasyi (Martapura), Tuan Guru Haji Syaukani Lc (Amuntai), Tuan Guru Haji Asmuni (Guru Danau), Tuan Guru Haji Muhammad Bakhet, Tuan Guru Haji Muhammad Ridwan (Guru Kapuh), Tuan Guru Haji Ahmad Syairazi, Tuan Haji Ahmad Barmawi (Guru Muda Kulur), Tuan Guru Haji Ahmad Sanusi (Guru Jaro), dan Tuan Guru Haji Zuhdiannor. Di antara kitab tasawuf yang membahas tentang tasawuf akhlaqi adalah kitab Nashâihuddîniyyah Wal Washâya Imâniyyah yang artinya adalah nasihat agama dan wasiat iman karya Imam Habib Abdullah Al-Haddad.

Di antara kitab tasawuf yang juga membahas tentang tasawuf akhlaqi adalah kitab AlHikam Al-'Athâiyyah. Kitab yang ditulis oleh Ibnu Atha'illah yang wafat pada tahun 709 H. Dalam kitab tersebut terdapat penjelasan tentang tentang akhlak atau adab dalam berdo'a yaitu dibahas pada bagian kedua dalam kitab tersebut.

Di antara kitab tasawuf yang membahas tentang tasawuf akhlaqi adalah kitab Kitab Bidâyatul Hidâyah yang merupakan salah satu kitab ilmu tasawuf karya Imam Al-Ghazali yang banyak dibaca dan dipelajari di majelis-mejelis pengajian Tuan Guru di Kalimantan Selatan. Di antara kitab tasawuf yang membahas tentang tasawuf akhlaqi adalah kitab Nashâihul 'Ibâd, salah satu kitab yang dipelajari di majelis-mjelis pengajian Tuan Guru di Kalimantan Selatan. Penulis kitab ini adalah Syekh Nawawi Banten yang memiliki nama lengkap Abu Abdu Al-Mu'ti Muhammad ibnu Umar Al-Tanara Al-Jawi Al-Bantani.

Al Qalam: Jurnal Ilmiah Keagamaan dan Kemasyarakatan Vol. 16, No. 2 Maret - April 2022 
Dijelaskan bahwa di dalam diri manusia ada potensi-potensi atau kekuatan-kekuatan. Ada yang disebut dengan fitrah yang cenderung kepada kebaikan. Ada juga yang disebut dengan nafsu yang cenderung kepada keburukan. Jadi, tasawuf akhlaqi yaitu ilmu yang memperlajari pada teori-teori perilaku dan perbaikan akhlak. Pada hakekatnya, para kaum sufi telah membuat sebuah sistem yang tersusun secara teratur yang berisi pokok-pokok konsep dan merupakan inti dari ajaran tasawuf. Diantaranya takhalli (menjauhkan diri dari kemaksiatan), tahalli (menghiasi diri dengan akhlak terpuji), tajalli (membuka tabir hijab antara manusia dengan Allah), munajât (mengeluh dan mengadu kepada Allah tentang kehidupan yang seorang hamba alami dengan untaian-untaian kalimat yang indah diiringi dengan pujian-pujian kebesaran nama Allah), murâqabah (kesadaran diri bahwa ia selalu berhadapan dengan Allah dalam keadaan diawasiNya), muhâsabah (analisis terhadap diri dan jiwa beserta sikap dan keadaannya yang selalu berubah-ubah), syari'at, thariqat, dan ma'rifat yang merupakan tujuan akhir dari tasawuf yakni mengenal Allah dengan sebenar-benarnya.

b. Tasawuf 'Amali

Tasawuf "Amali adalah tasawuf yang membahas tentang bagaimana cara mendekatkan diri kepada Allah. Terdapat beberapa istilah praktis dalam Tasawuf 'Amali, yakni syarî'at (segala ketentuan agama yang sudah ditetapkan oleh Allah untuk hambanya), tharîqat (jalan yang harus ditempuh oleh seorang sufi dalam mencapai tujuan berada sedekat mungkin dengan Tuhan), dan ma'rifat (pengetahuan yang sangat jelas dan pasti tentang tuhan yang diperoleh melalui sanubari).

Tuan Guru di Kalimantan Selatan juga mengajarkan tasawuf amali melalui Kitab tasawuf salaf yang berjudul Nashâihuddîniyyah Wal Washâya

c. Tasawuf Falsafi

Tasawuf Falsafi adalah tasawuf yang didasarkan kepada gabungan teori-teori tasawuf dan filsafat atau yang bermakana mistik metafisis, karakter umum dari tasawuf ini sebagaimana yang telah dikemukakan oleh Al-Taftazani bahwa tasawuf seperti ini: tidak dapat dikatagorikan sebagai tasawuf dalam arti sesungguhnya, karena teori-teorinya selalu dikemukakan dalam bahasa filsafat, juga tidak dapat dikatakan sebagai filsafat dalam artian yang sebenarnya karena teori-teorinya juga didasarkan pada rasa. Dalam tasawuf falsafi, yang lebih ditonjolkan pemikiran-pemikiran filosofis dengan ungkapan-ungkapan ganjilnya (syathahiyât) dalam ajaran-ajaran yang dikembangkannya. Ungkapan-ungkapan syathahiyât itu bertolak dari keadaan yang fanâ menuju pernyataan tentang terjadinya penyatuan ataupun hulǔl.

Adapun yang termasuk kategori ajaran tasawuf falsafi adalah:a. Fanâ' (tidak tampaknya sesuatu) dan Baqâ' (lenyapnya kesadaran dan kekal), b. Ittihâd, yaitu persatuan antara manusia

Al Qalam: Jurnal Ilmiah Keagamaan dan Kemasyarakatan Vol. 16, No. 2

Maret - April 2022 
Asmaran, Husnul Yaqin, Mahmud : Transmisi Ilmu Tasawuf Tuan Guru di Kalimantan Selatan

dengan Tuhan., c. Hulǔl, yaitu penyatuan sifat ketuhanan dengan sifat kemanusiaan., d. Wihdah al-Wujǔd, yaitu alam dan Allah adalah sesuatu yang satu., e. Isyrâq, yaitu pancaran cahaya atau iluminasi.

3. Metode Penerimaan dan Penyampaian Ilmu Tasawuf Tuan Guru di Kalimantan Selatan.

a. As-Shuhbah (berguru atau bersama dengan guru)

Ilmu tasaawuf menggunakan istilah shuhbah secara resmi yang untuk menggambarkan hubungan antara "murid" dan "mursyid", juga orang-orang yang berkecimpung dalam tarekat.

Tuan Guru Haji Muhammad Syukri Unus, Tuan Guru Haji Zarkasyi, Tuan Guru Haji Asmuni (Guru Danau), Tuan Guru Haji Syaukani, Tuan Guru Haji Muhammad Ridwan, Tuan Guru Haji Ahmad Syairazi, Tuan Guru Haji Ahmad Barmawi (Guru Muda Kulur), Tuan Guru Haji Ahmad Sanusi (Guru Jaro), Tuan Guru Haji Zuhdiannor (Guru Zuhdi) ketika waktu belajar dengan guru-gurunya lebih mengutamakan shuhbah dengan guru-gurunya atau dengan istilah pondok pesantren adalah berkhidmah dengan guru-gurunya dan mengikuti atau melaksanakan semua apa yang diperintahkan oleh guru-gurunya. Misalnya dengan menyapu lantai rumah gurugurunya, ikut mempersiapkan kegiatan majelis ta'lim guru-gurunya, menyediakan keperluan guru-gurunya ketika melaksanakan kegiatan majelis ta'lim, mempersiapkan kegiatan shalat hajat dan lain sebagainya. Karena beliau yakin dengan berkhidmah ilmu yang didapatkan akan lebih bermamfaat. Hal tersebut disampaikannya juga kepada semua murid-muridnya, sehingga sejak dahulu sampai sekarang banyak murid-muridnya yang berkhidmah kepadanya, silih berganti dan bahkan beliau menyediakan tempat tinggal dekat rumah beliau atau dekat majelis ta'lim beliau bagi murid-muridnya yang siap untuk berkhidmah kepada beliau sehingga murid-muridnya banyak yang berkhidmah kepadanya sampai puluhan tahun sebelum mereka pulang ke kampungkampung halamannya untuk melanjutkan estafet perjuangan guru-gurunya yaitu menyampaikan ilmu kepada murid-murid mereka.

.b. Riyadhah (latihan) dan Mujahadah (berjuang)

Riyadhah yang sering disebut sebagai latihan-latihan mistik, adalah latihan kejiwaan melalui upaya membiasakan diri agar tidak melakukan hal-hal yang mengotori jiwanya. Riyadhah harus disertai dengan mujahadah, yaitu kesungguhan dalam usaha untuk meninggalkan sifat-sifat buruk. Meninggalkan sifat-sifat buruk sangat berat sehingga membutuhkan kesungguhan dalam melatihnya. Perbedaan antara riyadhah dengan mujahadah adalah riyadhah berupa tahapantahapan real sedangkan mujahadah berusaha menekan atau mengendalikan masing-masing tahapan riyadhah dengan sungguh-sungguh. Meskipun demikian, riyadhah tidak dapat dipisahkan dari mujahadah karena keduanya ibarat dua sisi pada satu mata uang.

Al Qalam: Jurnal Ilmiah Keagamaan dan Kemasyarakatan Vol. 16, No. 2

Maret - April 2022 
Tuan Guru Haji Muhammad Syukri Unus adalah Tuan Guru yang sangat menyukai muthala'ah kitab-kitab aslafuna shalihin dan bersungguh-sungguh dalam mempelajarinya sehingga Ia terkenal sebagai Tuan Guru yang banyak berkarya dalam keilmuan Islam khususnya dalam bidang ilmu tasawuf. Sedangkan Tuan Guru Haji Zarkasyi lebih mengutamakan penanaman akhlak dalam kehidupan sehari-harinya dan lebih bersungguh-sungguh dalam beribadah. Ia lebih terkenal dengan ketawawhu'an (kerendahan hatinya) di hadapan orang lain dan murid-muridnya. Guru Danau biasanya menyampaikan langsung materi pengajian ilmu tasawuf kepada murid-muridnya, dan murid-muridnya pun mendengarkan langsung apa yang disampaikan oleh Guru Danau, dan murid- muridnya mencatat apa- apa yang yang dianggap mereka penting. Karena hal tersebut juga dilakukannya ketika Ia belajar ilmu-ilmu agama Islam dengan guru-gurunya khususnya ketika Ia belajar dengan Guru Sekumpul. Dan ketika Guru Danau menyampaikan ilmu tasawuf di pondok pesantren yang dibinanya,. kadang-kadang ia menyuruh muridnya untuk membacakan kitab tasawuf di hadapannya kemudian beliau mendengarkannya dan membenarkan bacaan muridnya ketika terdapat kesalahan dalam bacaannya. Kemudian setelah itu beliau menjelaskan maksud dari bacaan muridnya tersebut. Dalam pengajiannya Guru Danau sering memberikan amalan- amalan dalam kehidupan seharihari untuk murid-muridnya dan mengijazahkannya

Sebelum menyampaikan isi ceramah, guru Bakhiet sudah mengamalkannya terlebih dahulu. Ia lebih dahulu bersungguh-sungguh dalam mengamalkan apa yang akan disampaikannya kepada jama'ahnya atau murid-muridnya. Sehingga apa yang disampaikannya lebih membekas di hati para jama'ahnya atau murid-muridnya. Tuan Guru Haji Ahmad Syairazi lebih bersungguhsungguh dalam penanaman akhlak dalam kehidupan sehari-harinya dan lebih bersungguhsungguh dalam beribadah. Sehingga dengan akhlak dan budi pekertinya yang bagus menyebabkan Ia sangat disukai oleh banyak orang dan banyak jama'ah yang mau menimba ilmu kepadanya dari berbagai tempat. Tuan Guru Haji Ahmad Barmawi adalah seorang santri yang cerdas, beliau selalu menguasai apa yang diajarkan kakeknya, dan selalu melakukan muthala'ah dengan membaca sendiri kitab-kitab yang belum pernah diajarkan oleh gurunya. Oleh karena alasan terakhir inilah, beliau mampu mengajar di majelis-majelis pendidikan Islam dan pelajaranpelajaran agama pada tingkat dasar terhadap para santrinya terhadap para santri yang lain.

Tuan Guru Ahmad Sanusi (Guru Jaro), mendapatkan ilmu kebanyakannya dengan mendengarkan langsung ilmu-ilmu dari guru-gurunya, yaitu dengan sering mengikuti majelismajelis mereka seperti majelis pengajian Guru Sakumpul, majelis pengajian Ustadz H. M. Qasthalani, Lc, Banjarmasin, KH. Abdurrahim Yasin Lc, ataupun belajar langsung dengan Guru-

Al Qalam: Jurnal Ilmiah Keagamaan dan Kemasyarakatan Vol. 16, No. 2 Maret - April 2022 
Asmaran, Husnul Yaqin, Mahmud : Transmisi Ilmu Tasawuf Tuan Guru di Kalimantan Selatan

gurunya, seperti KH. Muhammad (Ayah Guru Zuhdi), Kyai Idris Jauhari (Pengasuh pondok pesantren al-Amin, Pemangkasan, Madura, Jawa Timur). Ketika belajar di pondok pesantren alFalah Guru Zuhdi mendengarkan langsung guru-gurunya menyampaikan ilmunya,dan mencatat apa-apa yang dianggapanya penting. Guru Zuhdi juga membaca kitab di hadapan gurunya dan gurunya mendengarkan. Guru Zuhdi pernah disuruh untuk membaca kitab di hadapan kawankawan dan gurunya, dan beliau mampu untuk membacakannya.

c. Dzikir

Secara etimologi, zikir adalah mengingat, sedangkan secara istilah adalah membasahi lidah dengan ucapan-ucapan pujian kepada Allah. Zikir merupakan metode lain yang paling utama untuk memperoleh ilmu ladunni. Tuan Guru Muhammad Syukri Unus mengambil talqin zikir idrissiyah dari Al-Habib Umar Al-Attas yang dilazimkannya untuk dibacanya setelah selesai shalat asar dan subuh, dan beliau melazimkannya juga untuk mengamalkan zikir tersebut kepada murid-muridnya untuk menjaga dan menguatkan iman yang pada diri seorang muslim.

Begitu juga Tuan Guru Haji Zarkasyi mengambil zikir idrissiyah dari Al-Habib Umar AlAttas yang dilazimkannya untuk dibacanya setelah selesai shalat asar dan subuh, dan beliau melazimkannya juga untuk mengamalkan zikir tersebut kepada murid-muridnya untuk menjaga dan menguatkan iman yang pada diri seorang muslim. Biasanya sebelum pengajian kitab-kitab khususnya dalam bidang tasawuf dimulai selalu diadakan pembacaan wirid, zikir, shalawat, dan taubat. yang dipimpin oleh Tuan Guru Haji Janawi dan setelah selesai pembacaan tersebut baru dimulai pengajian-pengajian kitab oleh Tuan Guru Haji Abdul Wahab Sya'rani. Hal tersebut juga diikuti oleh Mu'allim Haji Syaukani dalam menyampaikan ilmu tasawufnya kepada muridmuridnya.

Tuan Guru Muhammad Ridwan (Guru Kapuh), Tuan Guru Haji Ahmad Syairazi, Tuan Guru Haji Ahmad Barmawi (Guru Muda Kulur), Tuan Guru Haji Ahmad Sanusi (Guru Jaro), Tuan Guru Haji Zuhdiannor (Guru Zuhdi), mengambil zikir idrissiyah dari Guru Sekumpul yang dilazimkannya untuk dibacanya setelah selesai shalat asar dan subuh, dan beliau melazimkannya juga untuk mengamalkan zikir tersebut kepada murid-muridnya untuk menjaga dan menguatkan iman yang pada diri seorang muslim.

d. Tariqat

Tariqat adalah suatu cara atau pendakian yang ditempuh oleh para ahli tasawuf atau kaum mutasawwifin untuk mencapai tujuan. Dua Tuan Guru ilmu tasawuf di Martapura yaitu Tuan Guru Haji Muhammad Syukri dan Tuan Guru Haji Zarkasyi mengambil tarekat Sammaniyyah kepada Guru Sekumpul dan tarikat ini juga diikuti oleh murid-muridnya. Tuan Guru Haji Asmuni

Al Qalam: Jurnal Ilmiah Keagamaan dan Kemasyarakatan Vol. 16, No. 2

Maret - April 2022 
(Guru Danau) juga mengambil tarekat Sammaniyyah kepada Guru Sekumpul dan tarikat ini juga diikuti oleh murid-muridnya. Tuan Guru Haji Syaukani Lc mengambail tarikat Qadariyyah wa Naqsyabandiyyah dari Tuan Guru Haji Tarus melalui ayahnya sendiri. Ayahnya membai'atnya langsung setelah mendapat izin dari Tuan Guru Haji Tarus yaitu dengan membacakan silsilah sanad tarikat tersebut kepada Mu'allim Haji Syaukani.

Tuan Guru Haji Muhammad Bakhet diminta oleh orang ayahnya pergi belajar ilmu tarekat Alawiyah ke Bangil, Pasuruan, Jawa Timur, berguru kepada Habib Zainal Abidin bin Ahmad Al-Idrus, dari Surabaya. Setelah belajar ilmu tarekat Alawiyah tersebut selama satu tahun, Guru Bakhet diperintahkan oleh gurunya untuk memperkenalkan ajaran tersebut dengan syarat jama'ahnya tidak boleh kurang dari empat puluh orang. Setelah empat puluh orang jama'ah terkumpul, beliau memulai memperkenalkan ajaran tarekat Alawiyah. Pada awalnya, pengajian tarekat ini bertempat di pondok pesentren Hidayaturrahman di Barabai. Di tempat ini, pengajian hanya berlangsung selama empat puluh minggu atau empat puluh kali pertemuan.

Dua orang Tuan Guru ilmu tasawuf yang berada di kabupaten Hulu Sungai Selatan yaitu Tuan Guru Haji Muhammad Ridwan (Guru Kapuh) dan Tuan Guru Haji Ahmad Syairazi mengambil tarekat Sammaniyyah kepada Guru Sekumpul dan tarikat ini juga diikuti oleh muridmuridnya. Begitu juga Tuan Guru ilmu tasawuf yang berada di Rantau yaitu Tuan Guru Haji Ahmad Barmawi mengambil tarekat Sammaniyyah kepada Guru Sekumpul dan tarikat ini juga diikuti oleh murid-muridnya. Sedangkan Tuan Guru Haji Ahmad Sanusi (Guru Jaro) pergi ke Jawa mengambil sanad tarekat Naqsyabandiyah Qadariyah kepada khalifah pimpinan tarekat tersebut, kemuadian beliau mengambil tarekat Naqsyabandiyah uwaij di pakistan. Kemudian tarikat tersebut diajarkannya kepada murid-muridnya. Di Madinah Guru Jaro belajar ilmu-ilmu tasawuf kepada para masyaikh di Madinah dengan mengikuti majelis-mejelis pengajian mereka dan kadang-kadang ada juga yang langsung bertemu dengan para masyaikh di Madinah. Guru Jaro mengakui bahwa beliau lebih menyukai untuk belajar ilmu-ilmu tasawuf dan ma'rifah. Sedangkan Tuan Guru ilmu tasawuf yang berada di Banjarmasin yaitu Tuan Guru Haji Ahmad Zuhdiannor mengambil tarekat Sammaniyyah kepada Guru Sekumpul dan tarikat ini juga diikuti oleh murid-muridnya.

\section{Insiasi Spritual (bai'at/talqin)}

Inisiasi spiritual merupakan bentuk pelantikan atau peresmian seorang murid atau salik untuk bersungguh-sungguh melakukan usaha yang gigih (mujâhadah) dalam memerangi hawa nafsunya sehingga mampu memperolah kedekatan dengan Allah didepan seorang mursyid.

Al Qalam: Jurnal Ilmiah Keagamaan dan Kemasyarakatan Vol. 16, No. 2

Maret - April 2022 
Beberapa proses ceremonial inisiasi ini biasa disebut 'bai'at' atau 'talqin' yang berarti komitmen kesetiaan.

Tuan Guru ilmu Tasawuf di Kalimantan Selatan yang melakukan insiasi spiritual (bai'at/talqin) ini dalam majelis zikirnya. Sedangkan pada tariqat Naqsyabandiyah memiliki insiasi spiritual (bai'at/talqin) menggunakan kalimat syahadatain yang membentuk seperti gerakan tahiyyat akhir pada gerakan shalat. Adapun insiasi spiritual (bai'at/talqin) Darkah Yahlal Mandinah seperti yang terlihat pada gambar di bawah ini digunakan oleh jama'ah majelis Tuan Guru di Kalimantan Selatan secara umum saja, tidak terkait dengan majelis-majelis pengajian tertentu. Begitu juga insiasi spiritual (bai'at/talqin) berupa Jam'iyyah Ahlith Thariqah, hanya digunakan oleh jama'ah tarekat secara umum saja, tidak terikat pada majelis-majelis pengajian tertentu.

e. Pemakaian Khirqah (symbol)

Khirqah berarti pakaian, kain, atau Sobekan kain baju. Sedangkan sebagai istilah, khirqah adalah cenderamata sebagai bentuk pensanadan dan pengijazahan dalam tarekat kesufian. Kesufian atau tasawuf tidak berbeda dengan ilmu-ilmu lainnya, yang memiliki sanad yang tersambung hingga Rasulullah SAW. Al-khirqah, walau sebagai kata berarti hanya "sebuah pakaian", bahan yang dipergunakan, cara pemakaian, dan lain-lainnya, memiliki kekhususan tersendiri. Contoh lainnya seperti gerakan-gerakan tubuh saat berdzikir. Gerakan-gerakan ini memiliki kekhususan tersendiri yang menjadi identitas atau ciri khas mereka, yang hal tersebut telah menjadi turun-temurun sebagai sanad. Diantara Tuan Guru ilmu tasawuf di Kalimantan selatan yang menerima pemakaian khirqah adalah Tuan Guru Haji Muhammad Syukri Unus. Tuan Guru Haji Muhammad Syukri Unus menerima pemakaian khirqah sebagai bentuk ketersambungan dan ijazah sanad antara guru dan murid seperti musalsal pemakaian imamah, penyerahan tasbih, penyerahan tongkat, penjamuan tamu bilaswidatain (kurma dan air zam-zam), dan lain-lain. Hal tersebut disampaikannya juga kepada murid-muridnya yang ingin mengambil sanad ijazah tersebut kepadanya dan bahkan beliau menerima pelayanan pemberian sanad ijazah tersebut kepada beberapa rombongan dari daerah mana saja.

\section{SIMPULAN}

Berdasarkan paparan pada bab-bab sebelumnya, dapat disimpulkan sebagai berikut:

Jaringan ilmu tasawuf Tuan Guru di Kalimantan Selatan berporos pada beberapa daerah utama yaitu Martapura, Nagara (Kandangan), Barabai, Amuntai, Rantau (Tapin), Banjarmasin, dan Tabalong.

Al Qalam: Jurnal Ilmiah Keagamaan dan Kemasyarakatan Vol. 16, No. 2

Maret - April 2022 
Asmaran, Husnul Yaqin, Mahmud : Transmisi Ilmu Tasawuf Tuan Guru di Kalimantan Selatan

Materi penyampain ilmu tasawuf Tuan Guru di Kalimantan Selatan yaitu Pertama, Tasawuf Akhlaqi yang terdiri dari takhalli, tahalli, dan tajalli. Kitab yang membahasnya adalah Ihyâ 'Ulǔmuddin, Nashâihuddîniyyah, Al-Hikam, dan Bidâyatul Hidâyah. Kedua, Tasawuf Amali yang terdiri dari syarî'ah, tharîqah, haqîqah, dan ma'rifah. Kitab yang membahasnya adalah Ihyâ 'Ulǔmuddin, Nashâihuddîniyyah, Al-Hikam, dan Bidâyatul Hidâyah. Ketiga, Tasawuf Falsafi yang terdiri dari fanâ dan baqâ, ittihâd, hulǔl, wihdatul wujǔd, dan isyrâq. Kitab yang membahasnya adalah Kifâyatul Atqiyâ, Nashâihul 'Ibâd, Tuhfaturrâghibîn, dan Durrun Nafîs. Keempat, Manâqib yang terdiri dari manâqib Siti Khadijah dan manâqib Syekh Sammân AlMadâni. Kitab yang membahasnya adalah kitab manâqib Siti Khadijah dan kitab manâqib syekh Sammân Al-Madâni.

Metode penerimaan dan penyampaian ilmu tasawuf Tuan Guru di Kalimantan Selatan yaitu Pertama, Shuhbah berupa khidmah dan mulâzamah. Kedua, riyâdhah dan mujâhadah berupa pengamalan ilmu dan muthâla'ah. Ketiga, dzikir berupa râtib dan wirîd. Keempat, tharîqah berupa Sammâniyyah, Naqsyabandiyyah, Qadariyyah, dan Alawiyyah. Kelima, Insiasi Spritual berupa bai'at, tharîqat naqsyabandiyyah, darkah yahlal madinah, jam'iyyah ahli tharîqah. Keenam, khirqah berupa pemakaian imâmah, penyerahan tasbih, penyerahan tongkat, dan penjamuan tamu bil-aswidatain (kurma dan zam-zam).

\section{DAFTAR PUSTAKA}

Jaringan Ulama Timur Tengah dan Kepulauan Nusantara Abad XVII dan XVIII. Jakarta; Kencana, 2013

,........ The Transmission of Islamic Reformism to Indonesia: Network of Middle Eastern and Malay-Indonesian 'ulama in The Seventeenth and Eighteenth Centuie. Honolulu: Hawaii Press, 2004

Akhir, Noor Syahidah Mohamad, Pengaruh Syeikh Muhammad Nafis al-Banjari di Kalimantan Selatan Berhubung Ilmu Tasawuf dalam Prosiding Nadwah Ulama Nusantara (NUN) IV: Ulama Pemacu Transformasi Negara, Selangor: Universiti Kebangsaan Malaysia, 2011

Arifin, Miftah, Sufi Nusantara. Yogyakarta: ar Ruzz Media, 2013

AS, Asmaran., Pengantar Studi Tasawuf. Jakarta: Rajawali Pers, 1996

Al Qalam: Jurnal Ilmiah Keagamaan dan Kemasyarakatan Vol. 16, No. 2

Maret - April 2022 
Asmaran, Husnul Yaqin, Mahmud : Transmisi Ilmu Tasawuf Tuan Guru di Kalimantan Selatan

Azra, Azyumardi dan Oman Fathurrahman. Jaringan Ulama: Ensiklopedi Tematis Dunia Islam. Jakarta: Ichtiar Baru Van Hoeve, 2005

Badan Pusat Statistik, Provinsi Kalimantan Selatan Dalam Angka. Banjarmasin: CV.Karya Bintang Musim, 2017

Muis, Gt. Abd., Masuk dan Tersebarnya Islam di Kalimantan Selatan, makalah disampaikan dalam Pra Seminar Sejarah Kalimantan Selatan Tanggal 23-25 September 1973

Mujiburrahman, "Tasawuf di Masyarakat Banjar: Kesinambungan dan Perubahan Tradisi Keagamaan” dalam Kanz Philosophia, Volume 3, No.2, Desember 2013

Mujiburrahman, Selayang Pandang Ulama Banjar Dari Masa Ke Masa, Banjarmasin: Abadi Offset, 2011

Saifuddin, Transmisi Hadits Dan Kontribusinya Dalam Pembentukan Jaringan Keilmuan Dalam Islam. Jurnal Ilmu Ushuluddin, Vol. 8, No. 2: 2009

Ulfatunhasanah, Pesantren Dan Transmisi Keilmuan Islam Melayu-Nusantara (Literasi, Teks, Kitab, dan Sanad Keilmuan). Anil Islam, Vol. 8.

Zarkasyi, Maimunah, Pemikiran Tasawuf Muh Arsyad Al-Banjari dan Pengaruhnya di Masyarakat Kalimantan Selatan. dalam Jurnal ISLAMICA, Vol. 3, No. 1, September 2008

Zuhairini dan Abdul Ghofir, Metodologi Pembelajaran Malang: UM PRESS, 2004

Al Qalam: Jurnal Ilmiah Keagamaan dan Kemasyarakatan Vol. 16, No. 2

Maret - April 2022 